\title{
Seminoma Clinical Stage 1 - Patterns of Care in Germany
}

\author{
Klaus-Peter Dieckmann ${ }^{a}$ Inken Dralle-Filiz ${ }^{a}$ Julia Heinzelbecker ${ }^{d}$ \\ Cord Matthies $^{\text {b Jens Bedke }}{ }^{\mathrm{e}}$ Jörg Ellinger ${ }^{g}$ Jörg Sommer ${ }^{\text {h }}$ Björn Haben ${ }^{i}$ \\ Rainer Souchon ${ }^{f}$ Petra Anheuser ${ }^{a}$ Uwe Pichlmeier ${ }^{c}$ \\ ${ }^{a}$ Klinik für Urologie, Albertinen-Krankenhaus Hamburg, ${ }^{b}$ Abteilung für Urologie, Bundeswehr-Krankenhaus \\ Hamburg, and ' Institut für Epidemiologie und Medizinische Statistik, Universitätsklinikum Eppendorf, Hamburg, \\ ${ }^{\mathrm{d}}$ Klinik für Urologie, Universitätsklinikum Mannheim, Mannheim, ${ }^{\mathrm{e}} \mathrm{Klinik}$ für Urologie and ${ }^{\mathrm{f}} \mathrm{Klinik}$ für Radio- \\ Onkologie, Universitätsklinikum Tuebingen, Tuebingen, ${ }^{9}$ Klinik für Urologie, Universitätsklinikum Bonn, Bonn, \\ ${ }^{h}$ Klinik für Urologie, St. Franziskus Hospital Lohne, Lohne, and 'Abteilung für Urologie, St. Marien Krankenhaus \\ Ahaus, Ahaus, Germany
}

\section{Key Words}

Testicular germ cell neoplasms · Seminoma $\cdot$ Patterns of care $\cdot$ Carboplatin $\cdot$ Surveillance $\cdot$ Radiotherapy

\begin{abstract}
Introduction: International guidelines are ambivalent regarding the recommendations for the management of clinical stage 1 (CS1) seminoma. Patients and Methods: During 2008-2013, 1,050 patients with seminoma CS1 were prospectively registered with regard to assessing management modality (radiotherapy, carboplatin, surveillance). Associations with tumor size, rete testis invasion, age, year of diagnosis, type of institution, and geographic location were assessed. Results: Of the total number of patients, $49.3 \%$ received carboplatin 1 course, $8.5 \%$ carboplatin 2 courses, $35.9 \%$ surveillance, and $6.3 \%$ radiotherapy. In 2013, surveillance increased significantly to $57.9 \%$. Treatment decisions were significantly associated with rete testis invasion and tumor size. Carboplatin was applied significantly more in office clinics than elsewhere. There is some regional variation re-
\end{abstract}

\section{KARGER}

E-Mail karger@karger.com

www.karger.com/uin garding treatment preferences. Conclusions: The rising acceptance of surveillance mirrors international trends. The associations with prognostic factors demonstrate care givers to be compliant with contemporary guidelines. The association with the type of institution suggests non-oncological factors to be also relevant in decision making.

(c) 2016 S. Karger AG, Basel

\section{Introduction}

Testicular germ-cell tumors (GCTs) represent the most common malignancy in middle-aged men in Northern European countries [1]. Nevertheless, the mortality rates remain low, as highly effective management modalities are available [2]. Seminoma represents the most frequent histologic type comprising about $55 \%$ of GCT cases [3]. Clinical stage 1 (CS1) is defined as the absence of metastases evidenced by clinical examination, imaging studies and laboratory investigation. Today, up to 3 quarters of all seminoma cases are diagnosed with

\footnotetext{
Prof. Klaus-Peter Dieckmann

Klinik für Urologie

Albertinen-Krankenhaus Hamburg, Suentelstrasse 11a

DE-22457 Hamburg (Germany)

E-Mail DieckmannKP@t-online.de
} 
this stage, rendering CS1 seminoma the most frequent subgroup of GCTs $[4,5]$, and the most important constellation of GCT in daily practice. After inguinal orchiectomy, 3 options for CS1 seminoma patients are available. Traditionally, abdominal radiotherapy was the preferred option because microscopic metastatic spread to the retroperitoneal lymph nodes and may be present despite normal imaging results [6-9]. Although radiotherapy produces excellent durable cure rates, this management strategy was challenged due to rising concerns over possible long-term toxicities as the induction of second malignancies [10]. Surveillance strategies emerged as an alternative justified by the experience of highly effective cisplatin-based therapy even in relapsing cases with advanced GCT $[11,12]$. Surveillance strategies avoid any treatment toxicity until the progression of seminoma is evident. Carboplatin chemotherapy developed as a further alternative to radiotherapy because of its favorable toxicity profile [13]. Initially, this drug was administered twice with 4 weeks apart [14]. Later on, 1 course of carboplatin AUC 7 was considered effective as the original 2 -course regimen [15]. All of the treatment strategies for CS1 seminoma produced long-time survival rates of at least $99 \%$ and were thus considered equivalent [16]. It is important to note that the different international guidelines on GCTs differ in their recommended management strategies for CS1 seminoma [2,17-22]. To date, only a few studies have addressed the patterns of care regarding the management of testicular seminoma in particular countries [23]. We explored the current practice patterns regarding the treatment of CS1 seminoma in Germany. Furthermore, we evaluated possible influencing factors that might have an impact on treatment decisions.

\section{Patients and Methods}

The 'National Seminoma Registry Study' (NSR study) aimed at displaying the patterns of care in terms of adjuvant treatment of patients with CS1 testicular seminoma in Germany. At the outset of the study, the European consensus group recommendations authored by Krege et al. [24] represented the well-accepted standards of seminoma management. Accordingly, 4 adjuvant management modalities were considered appropriate: surveillance, abdominal radiotherapy, 1 course of carboplatin, or 2 courses of carboplatin. According to the study protocol, only the elected treatment modality was registered. Treatment decisions were correlated with the following clinical parameters: age at diagnosis (years), size of the primary tumor $(\mathrm{cm})$, presence of rete testis invasion (yes/no), and the year of treatment (2008-2013). Furthermore, the following socio-epidemiological parameters were included: type of institution (university hospital, municipal hospital, office clinic) and its geographic location (according to the Zip code, 'Postleitzahl'). For the
Table 1. Patients characteristics

\begin{tabular}{llc}
\hline \multicolumn{2}{l}{ Eligible, $\mathrm{n}$} \\
\hline Patients, total, $\mathrm{n}$ & 1,050 & \\
Age, years & 1,050 & \\
$\quad$ Mean \pm SD & & $41.3 \pm 10.5$ \\
$\quad$ Median (IQR) & & $41(34-48)$ \\
$\quad$ Range & 1,027 & $369(35.9)$ \\
Rete testis invasion: yes, n (\%) & \\
Tumor size, cm & 1,029 & $3.67 \pm 2.1$ \\
$\quad$ Mean & & $3.4(2.0-4.9)$ \\
$\quad$ Median (IQR) & & $0.2-16$ \\
$\quad$ Range & 1,050 & \\
Year of diagnosis, $\mathrm{n}$ & & 61 \\
2008-2009 & & 294 \\
2010 & & 296 \\
2011 & & 202 \\
2012 & 197 \\
2013 & & \\
Type of institution, $\mathrm{n}$ & & \\
University department & & 215 \\
Municipal hospital & & 785 \\
Office clinic & & 50 \\
\hline
\end{tabular}

analysis of associations of treatment decisions with the various parameters, the 2 carboplatin regimens ( 1 and 2 courses, respectively) were taken as one group because the 2 procedures are not grossly different clinically, and the sample size of the 2-course group is very much smaller than that of the other group.

All patients gave informed consent to the registration for the study. The NSR study was approved by the local Ethical Committee (Ärztekammer Hamburg, PV 3123).

From 2008 to 2013, a total of 1,050 patients with testicular seminoma CS1 were prospectively registered from 130 urologic institutions in Germany. A list of the participating institutions, ranked according to the number of cases enrolled is given in the appendix. Clinical details and socioepidemiological features of the entire cohort are given in table 1 .

All of the data were prospectively filed in a commercially available database system (MS Excel). We evaluated the relative frequency of the management modalities for the entire study period (2008-2013). 95\% CIs were calculated for proportions. We then calculated the relative frequency of each applied management modality per consecutive years of the study period. The chi-square test was used to test for temporal trends across years and for associations of treatment decisions with rete testis invasion and the type of institution. Associations of the management decisions with tumor size and patient age were evaluated with the Kruskal-Wallis test. Possible associations with the location of the institution were analyzed by descriptive methods. Because of underprovided data from several German federal states (Bundesländer), the statistical analysis involved only pairwise comparisons with the chi-square test using the federal state of Hamburg as reference. All of the final statistical analyses were performed with the SAS software package version 9.3 (SAS Institute, Inc., Cary, N.C., USA) on a Windows platform. 
Table 2. Utilization of treatment modalities during the entire observation period 2008-2013

\begin{tabular}{lcrc}
\hline & $\mathrm{n}$ & $\%$ & $95 \% \mathrm{CI}^{\mathrm{a}}$ \\
\hline Treatment modality & & & \\
Surveillance & 377 & 35.9 & $32.2-39.7$ \\
Radiotherapy & 66 & 6.3 & $4.6-8.3$ \\
Carboplatin 1 course & 518 & 49.3 & $45.4-53.2$ \\
Carboplatin 2 courses & 89 & 8.5 & $6.5-10.8$ \\
\hline Treatment modality (carboplatin 1 group) & & \\
Surveillance & 377 & 35.9 & $32.2-39.5$ \\
Radiotherapy & 66 & 6.3 & $4.7-8.3$ \\
Carboplatin & 607 & 57.8 & $54.1-61.5$ \\
\hline Total & 1,050 & 100 & \\
\hline
\end{tabular}

${ }^{a}$ Multinomial exact CI.

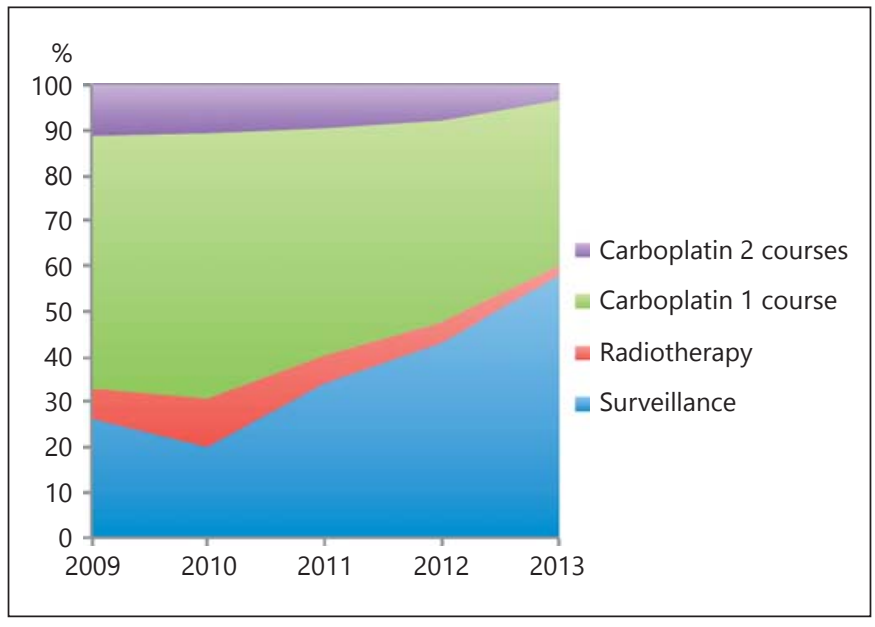

Fig. 1. Utilisation of treatment modalities - changes over time.

Table 3. Treatment modalities grouped by year of treatment

\begin{tabular}{|c|c|c|c|c|c|c|}
\hline $\begin{array}{l}\text { Year of diagnosis, } \\
\mathrm{n}(\%)\end{array}$ & $\begin{array}{l}\text { Surveillance } \\
(\mathrm{n}=377)\end{array}$ & $\begin{array}{l}\text { Radiotherapy } \\
(\mathrm{n}=66)\end{array}$ & $\begin{array}{l}\text { Carboplatin } 1 \\
\text { course }(n=518)\end{array}$ & $\begin{array}{l}\text { Carboplatin } 2 \\
\text { courses }(n=89)\end{array}$ & $\begin{array}{l}\text { Total } \\
(\mathrm{n}=1,050)\end{array}$ & $\begin{array}{l}\text { Pairwise } \mathrm{p} \text { values } \\
\text { (chi-square test) }^{\mathrm{a}}\end{array}$ \\
\hline 2008-2009 & $16(26.2)$ & $4(6.6)$ & $34(55.7)$ & 7 (11.5) & $61(100.0)$ & $<0.0001$ \\
\hline 2010 & $59(20.1)$ & $31(10.5)$ & $173(58.8)$ & $31(10.5)$ & $294(100.0)$ & $<0.0001$ \\
\hline 2011 & $101(34.1)$ & $18(6.1)$ & $149(50.3)$ & $28(9.5)$ & $296(100.0)$ & $<0.0001$ \\
\hline 2012 & $87(43.1)$ & $9(4.5)$ & $90(44.6)$ & $16(7.9)$ & $202(100.0)$ & 0.009 \\
\hline 2013 & $114(57.9)$ & $4(2.0)$ & $72(36.5)$ & $7(3.6)$ & $197(100.0)$ & \\
\hline
\end{tabular}

a The year 2013 is reference for pairwise comparisons.

\section{Results}

The most frequent treatment modality was one course of carboplatin, which was applied in $49.3 \%$ of the cases. Noteworthy, radiotherapy was applied only to $6.3 \%$ of the seminoma patients. The relative frequencies of the treatment modalities are given in table 2.

There was a significant shift over time regarding the relative frequencies of treatment modalities from 2008 to 2013 ( $\mathrm{p}<0.0001$ ). Surveillance ranked second in 2008 behind carboplatin and experienced a constant increase ever since to become the first ranking modality with $57.9 \%$ of the cases in 2013. Details are given in table 3 and figure 1.

The tumor size was significantly associated with the treatment decisions (table 4). Patients allocated to sur- veillance had a significantly smaller median tumor size $(2.6 \mathrm{~cm})$ than those submitted to radiotherapy $(4.1 \mathrm{~cm})$ and carboplatin $(4.0 \mathrm{~cm})(\mathrm{p}<0.0001)$. Upon categorizing tumor size by $1 \mathrm{~cm}$ increments, surveillance is the most frequent modality among patients with tumor size of less than $2 \mathrm{~cm}(51.0 \%$ of this category, $10.7 \%$ of all cases). Among those with tumors larger than $5 \mathrm{~cm}$, carboplatin is the predominant treatment modality $(76.0 \%$ of this category, and $18.9 \%$ of all cases; $\mathrm{p}<0.0001$ ).

Rete testis invasion is likewise associated with the treatment decisions (table 4 ). Only $19.8 \%$ of patients with rete testis invasion were submitted to surveillance, while the remainder received carboplatin or adjuvant radiotherapy, respectively (72.9 and 7.3\%; $\mathrm{p}<0.0001$ ).

Age was not associated with the treatment decisions (table 4) by overall analysis. Yet, by pairwise comparison 
Table 4. Association of treatment decisions with clinical factors (the 2 carboplatin groups are grouped)

\begin{tabular}{|c|c|c|c|c|}
\hline Eligible, $\mathrm{n}$ & 372 & 65 & 592 & 1,029 \\
\hline Mean (SD) & $2.96(1.69)$ & $4.05(2.13)$ & $4.07(2.21)$ & $3.67(2.10)$ \\
\hline Median (IQR) & $2.60(1.80-4.00)$ & $4.10(2.50-5.00)$ & $4.00(2.40-5.30)$ & $3.40(2.00-4.90)$ \\
\hline $\mathrm{p}$ value (Kruskal-Wallis test) & & & & $<0.0001$ \\
\hline Pairwise $\mathrm{p}$ values (Kruskal-Wallis test) ${ }^{\mathrm{a}}$ & & $<0.0001$ & $<0.0001$ & \\
\hline \multicolumn{5}{|l|}{ Rete testis invasion, $\mathrm{n}(\%)$} \\
\hline No & $295(44.8)$ & $37(5.6)$ & $326(49.5)$ & $658(100.0)$ \\
\hline Yes & $73(19.8)$ & $27(7.3)$ & $269(72.9)$ & $369(100.0)$ \\
\hline Missing information & $9(39.1)$ & $2(8.7)$ & $12(52.2)$ & $23(100.0)$ \\
\hline Mean (SD) & $40.5(10.7)$ & $41.7(9.3)$ & $41.7(10.5)$ & $41.3(10.5)$ \\
\hline Median (IQR) & $40.0(33.0-47.0)$ & $41.0(35.0-45.0)$ & $42.0(34.0-48.0)$ & $41.0(34.0-48.0)$ \\
\hline Range & $20-82$ & $25-73$ & $17-82$ & $17-82$ \\
\hline p value (Kruskal-Wallis test) & & & & 0.1367 \\
\hline Pairwise $\mathrm{p}$ value (Kruskal-Wallis test) ${ }^{\mathrm{a}}$ & & 0.4450 & 0.0484 & \\
\hline
\end{tabular}

${ }^{a}$ Reference for pairwise comparisons: surveillance. IQR = Interquartile range.

with surveillance, carboplatin treatment was associated with older age $(\mathrm{p}=0.0484)$.

The type of institution had a significant influence on the treatment decision (table 5; $\mathrm{p}=0.0093$ ). University hospitals did more frequently advocate surveillance strategies ( $45.1 \%$ of their patients) than municipal hospitals (33.8\%) and office clinics (30\%). Conversely, carboplatin was the most frequent modality chosen in office clinics (68.0\% of their patients), while municipal hospitals (59.1\%) and university departments (50.7\%) applied this therapy less frequently $(\mathrm{p}=0.0104)$.

The evaluation of possible associations of treatment decisions with geographic regions is hampered by a skewed distribution of the study population across the German federal states. Roughly two thirds of the entire study population $(n=765)$ derive from the 5 federal states Baden-Württemberg, Hamburg, Bayern, Niedersachsen and Nordrhein-Westfalen, while the other eleven countries contribute only one third of the population. If exclusively the former 5 regions were evaluated (table 6), there was indeed some variance visible regarding the preferences for a particular treatment modality. Bayern ranked first in applying radiotherapy to $20.9 \%$ of the patients $(\mathrm{p}<0.0001)$. Niedersachsen ranked first with the application of carboplatin chemotherapy to $70.7 \%$ of the patients $(\mathrm{p}=0.0478)$. Baden-Württemberg ranked first with respect to surveillance with $48.6 \%$ of the patients ( $\mathrm{p}=$ 0.3575 , not significant).

\section{Discussion}

This is the first evaluation of patterns of care of CS1 seminoma in Germany. The most striking result is the continuous rise of surveillance during the study period until it became the preferred treatment modality in 2013. At the same time, we noted a shift from carboplatin chemotherapy that ranked first in 2008 to surveillance ranking first in 2013. Probably, the European Association of Urology guidelines that were newly re-issued in 2011 [2] had a significant bearing on treatment decisions, particularly, as these guidelines are popularized by the well-accepted second opinion network for GCT in Germany $[25,26]$. The rising trend of surveillance in Germany was first observed in an evaluation of the second opinion network in 2013 [27]. A survey 
Table 5. Association of treatment decision with type of institution

\begin{tabular}{|c|c|c|c|c|c|}
\hline Type of institution, n (\%) & $\begin{array}{l}\text { Surveillance } \\
(\mathrm{n}=377)\end{array}$ & $\begin{array}{l}\text { Radiotherapy } \\
(\mathrm{n}=66)\end{array}$ & $\begin{array}{l}\text { Carboplatin } \\
(\mathrm{n}=607)\end{array}$ & $\begin{array}{l}\text { Total } \\
(\mathrm{n}=1,050)\end{array}$ & $\begin{array}{l}\text { Pairwise } \mathrm{p} \text { values } \\
\text { (chi-square test) }^{\mathrm{a}}\end{array}$ \\
\hline Office clinic & $15(30.0)$ & $1(2.0)$ & $34(68.0)$ & $50(100.0)$ & 0.0839 \\
\hline Municipal hospital & $265(33.8)$ & $56(7.1)$ & $464(59.1)$ & $785(100.0)$ & 0.0056 \\
\hline University department & $97(45.1)$ & $9(4.2)$ & $109(50.7)$ & $215(100.0)$ & \\
\hline \multicolumn{4}{|c|}{ Overall p value (chi-square test) } & 0.0093 & \\
\hline
\end{tabular}

${ }^{a}$ Reference for pairwise comparisons: University department.

Table 6. Treatment decisions in select German federal states

\begin{tabular}{llllrr}
\hline Country, n (\%) & $\begin{array}{l}\text { Surveillance } \\
(\mathrm{n}=377)\end{array}$ & $\begin{array}{l}\text { Radiotherapy } \\
(\mathrm{n}=66)\end{array}$ & $\begin{array}{l}\text { Carboplatin } \\
(\mathrm{n}=607)\end{array}$ & $\begin{array}{l}\text { Total } \\
(\mathrm{n}=1,050)\end{array}$ & \multicolumn{1}{c}{$\begin{array}{l}\text { Pairwise p value } \\
(\text { chi-square test) }\end{array}$} \\
\hline Baden-Württemberg & $67(48.6)$ & $5(3.6)$ & $66(47.8)$ & $138(100)$ & 0.3575 \\
Bayern & $29(26.4)$ & $23(20.9)$ & $58(52.7)$ & $110(100)$ & $<0.0001$ \\
Hamburg & $99(44.4)$ & $4(1.8)$ & $120(53.8)$ & $223(100)$ & \\
Niedersachsen & $21(18.0)$ & $1(1.3)$ & $53(70.7)$ & $75(100)$ & \multicolumn{1}{c}{0.0376} \\
Nordrhein-Westfalen & $75(34.2)$ & $9(4.1)$ & $135(61.6)$ & $219(100)$ & 0.0478 \\
All other states & $86(30.2)$ & $24(8.4)$ & $175(61.4)$ & $285(100)$ & $<0.0001$ \\
\hline
\end{tabular}

${ }^{\text {a }}$ Reference for pairwise comparison is Hamburg.

among physicians treating seminoma patients in Europe revealed greatly differing treatment recommendations among various specialties and countries [28]. In the United Kingdom (UK), a decrease of radiotherapy utilization has been observed to a similar extent as documented in Germany and also Scandinavia [29]. Currently, up to $66 \%$ of seminoma patients receive carboplatin chemotherapy in the United Kingdom; however, simultaneously, surveillance is gaining acceptance [30]. A recent report from Australia revealed that carboplatin was the most accepted treatment modality comprising about $62 \%$ of patients. About $33 \%$ are referred to surveillance regimens and only $5 \%$ receive radiotherapy [31]. Noteworthy, radiotherapy is still the most popular treatment for seminoma patients in the United States and in Eastern European countries [28, 32]. However, surveillance and carboplatin are slowly gaining shares [33].

The evaluation of practice patterns is a rather new field of clinical research [34]. Formal clinical trials usually enroll highly selected patients and apply high and rigid standards of quality control. However, daily clinical practice is different and often, the excellent results of pace-making clinical trials are not fully reproducible in clinical reality [35]. Patterns of care analyses aim to unveil this gap between scientific trials and clinical reality and seek to open avenues to narrow the gap [36]. With regard to testicular cancer, a number of patterns of care analyses have already been reported on the international level $[4,37,38]$. In Germany, the current study is the first one to analyze on a national level how guideline recommendations accord with the way testicular cancer patients are actually treated.

Another notable result of this study is the association of treatment decisions with various parameters. Expectedly, the established prognostic parameters for tumor progression, that is, tumor size and rete testis invasion [39] were significantly associated with treatment decisions. This observation is in accordance with the current guidelines and suggests that guidelines are accepted in daily practice.

Higher age is weakly associated with the decision for carboplatin chemotherapy. This result is surprising as younger age has been suggested to be a prognostic factor for progression [40]. Accordingly, one could have expected more decisions for carboplatin in younger patients. On 
the other hand, sound evidence on the association of younger age and progression is still lacking, partly explaining our unexpected observation.

Treatment decisions might well have been influenced by other factors, for example, the patient's mental status, the wish for paternity, job-related problems, and other sociodemographic factors. Also, the presence of contralateral testicular intraepithelial neoplasia could impact on decision making. However, all of these aspects could not be explored with the tools used in this study.

Another surprising result is the association of treatment decisions with the type of institution. The reasons why office clinics prefer carboplatin regimens remain elusive. Possibly, reasons beyond clinico-oncological considerations as economic incentives might affect decision making in the office clinic setting, but evidence for this hypothesis is lacking. University departments are dedicated to acknowledge new ideas and to test novel treatment strategies. Thus, surveillance, which represents the most novel strategy in seminoma might be predominantly applied by university departments.

The differences of practice patterns between different German federal states as observed in this study should be interpreted carefully because of underprovided data from several federal states. Statistical bias cannot be ruled out since numbers are small in the particular subgroups. On the other hand, 4 of the larger states (NordrheinWestfalen, Baden-Württemberg, Bayern, and Niedersachsen) were well represented in the study, allowing at least some cautious explorations. A striking finding is the persisting high utilization of radiotherapy with $20 \%$ of cases in Bayern. This finding disaccords with national and international trends $[29,41,42]$ and is at variance with the recent guideline recommendations [2] and the nationwide operating second opinion network on GCT [25]. The preference of surveillance regimens observed in Baden-Württemberg may be related to the high number of patients recruited from university departments in this state, as surveillance according to our findings was the preferred treatment modality in university departments.

Strengths of this study involve the prospective way of patient recruitment as well as the large number of CS1 patients included. The number of missing parameters per case is low; thus, the data can be considered robust. As we only noted the treatment recommendation given by the institution performing the primary management (i.e. orchiectomy and primary staging), we do not know whether or not these recommendations had been followed in the later course. The lack of information re- garding the compliance of local physicians with the original recommendations is a clear limitation of the study. However, confounding the study results by noncompliance is probably low because in most of the cases the adjuvant treatment recommended is usually applied in the same institution. Only surveillance strategies are implemented by office urologists. Another limitation is clearly the voluntary study character because in this setting (other than in a compulsory registry), several centers apparently did not report all of the seminoma cases treated. This view is substantiated by the low number of registered patients in many of the participating centers although higher incidence rates were likely prevalent. However, in light of a lacking National Cancer registry in Germany with compulsory documentation of clinical data by treatment providers, a more accurate description of the patterns of care seems hardly possible in this country.

\section{Conclusion}

This study is the first patterns-of-care analysis regarding the management of CS1 testicular seminoma patients in Germany. A significant increase in surveillance regimens was documented with a simultaneous decrease of carboplatin chemotherapy. Treatment decisions were associated with the known prognostic factors of tumor size and rete testis invasion. Age was only weakly associated with treatment decision. One unexpected result was the association of treatment decisions with the type of institution. In particular, the preference of carboplatin therapy in office clinics and the preference of surveillance in university departments have been documented for the first time. In terms of regional variances, an ongoing high utilization of radiotherapy in Bayern and a high rate of surveillance in Baden-Württemberg was notable.

\section{Acknowledgments}

The NSR study was supported by the 'Hamburger Stiftung zur Förderung der Krebsbekämpfung' (grant No. 180/2009). The authors are grateful to 130 institutions in Germany (appendix) for enrolling patients to this study.

\section{Disclosure Statement}

The authors declare no conflicts of interests with the article. 


\section{Appendix}

Contributing Institutions Ranked by the Number of Cases Enrolled

Hamburg, Bundeswehr Krankenhaus

Hamburg, Albertinen-Krankenhaus

Tuebingen, Urologische Universitätsklinik

Trier, Krankenhaus der Barmherzigen Brüder

Mannheim, Urologische Universitätsklinik

Lohne, St. Franziskus Krankenhaus

Bonn, Urologische Universitätsklinik

Siegen, Jung-Stilling Krankenhaus

Ahaus, St. Marien Krankenhaus

Chemnitz, Zeisigwaldkliniken

Leipzig, St. Elisabeth Krankenhaus

Berlin, St. Hedwig Krankenhaus

Freiburg, Universitätsklinik

Karlsruhe, Städtisches Klinikum

Gladbeck, St. Barbara Hospital

Bergisch Gladbach, Marien-Krankenhaus

Köln, Heilig Geist Krankenhaus

Köln, Urologgia

Magdeburg, Universitätsklinik

Münster, Universitätsklinik

Reichenbach, Paracelsus-Klinik

Amberg, Klinikum St. Marien

Berlin, Bundeswehrkrankenhaus

Coburg, Städtisches Klinikum

Kaiserslautern, Westpfalzklinikum

Gütersloh, Städtisches Klinikum

München, Klinikum Bogenhausen

Ulm, Bundeswehrkrankenhaus

Würzburg, Julius Maximilian Universität

Frankfurt, Universitätsklinik

Fulda, Klinikum

Rüsselsheim, Klinikum

Schweinfurt, Leopoldina-Krankenhaus

Erlangen, Waldkrankenhaus St. Marien

Flensburg, Diako Klinikum

Frankfurt, Städtische Kliniken Höchst

Klinikum Ingolstadt

Köln, St. Elisabeth Krankenhaus

Lübbecke, Krankenhaus

Bad Tölz, Asklepios Stadtklinik

Hamm, St. Barbara Klinik

Herzberg, Urologie Herzberg

Jena, Urologische Universitätsklinik

Löningen, St. Anna Stift

Mönchengladbach, Maria Hilf Krankenhaus

Schwäbisch Hall, Diakonie Klinikum

Aachen, Urologische Universitätsklinik

Freiberg, Kreiskrankenhaus

Gera, Waldklinikum

Göttingen, Urologische Universitätsklinik

Köln, Dr. Klier

Geestland, Seepark Klinik

Plauen, Helios Klinikum

Aschersleben, Kreiskliniken
Berlin, Universitätsklinikum Charité

Bonn, Waldkrankenhaus

Erfurt, Krankenhaus St. Nepomuk

Hameln, Kreiskrankenhaus

Koblenz, Bundeswehrkrankenhaus

Lübeck, Universitätsklinikum Schleswig-Holstein

Reifenstein, Eichsfeld Klinikum

Wetzlar, Klinikum

Datteln, St. Vincenz Krankenhaus

Fürth, Klinikum

Garmisch-Partenkirchen, Klinikum

Gießen, Urologische Universitätsklink

Kempten, Klinikum

Köln, Urologische Universitätsklinik

Mannheim, Diakonie-Krankenhaus

Pforzheim, Siloah St. Trudpert Klinikum

Schwerin, Helios Kliniken

Stralsund, Helios Hanse Klinikum

Wilhelmshaven, Reinhard-Nieter-Krankenhaus

Bad Bergzabern, Klinikum Landau

Baden-Baden, Dr. Brüggeboes

Bautzen, Oberlausitzkliniken

Berlin, Helios Kliniken

Berlin, Vivantes Auguste-Victoria-Krankenhaus

Dresden, Diakonissenkrankenhaus

Fürstenfeldbruck, Urologisches Zentrum

Hamm, St. Josef Krankenhaus

Homburg, Urologische Universitätsklinik

Münster, Herz-Jesu-Krankenhaus

Nürnberg, ÜGP

Solingen, Städtisches Klinikum

Ulm, Urologische Universitätsklinik

Augsburg, Klinikum

Bad Hersfeld, Klinikum

Bamberg, Klinikum Bruderwald

Bonn, Malteser Krankenhaus

Detmold, Klinikum Lippe

Frankfurt, Praxisklinik Prof. Bickeböller

Gehrden, Robert-Koch-Krankenhaus

Göttingen, Evangelisches Krankenhaus Weende

Hamburg, Praxisklinik Dr. Heitz

Hamburg, Praxisklinik Dr. Soyka

Hamburg, Universitätsklinikum Eppendorf

Hannover, Friederikenstift

Heidelberg, Krankenhaus Salem

Itzehoe, Klinikum

Lauchhammer, Klinikum Niederlausitz

Lüdenscheid, Märkische Kliniken

Magdeburg, Klinikum

Nürnberg, Theresien-KH

Rostock, Urologische Universitätsklinik

Schwedt, Asklepios Klinik

Stuttgart, Katharinenhospital

Würzburg, Juliusspital 
Amberg, Praxisklinik Dres. Scharl/Vogel/Schreyer

Bad Nauheim, Praxisklinik Dr. Focke

Bitburg, Praxisklinik Dres. Zender/Müller

Bremen Praxisklinik am Klinikum Bremen-Nord

Bremen, Klinikum Bremen-Mitte

Deggendorf, Klinikum

Dessau, Diakonie-Krankenhaus

Frechen, St. Katharinen Krankenhaus

Hamburg, Asklepios Klinik Barmbek

Hamburg, Praxisklinik Dr. Bünz

Hannover, Siloah Krankenhaus

\author{
Herne, Marienhospital \\ Kempen, Hospital zum Heiligen Geist \\ Köln, Krankenhaus Holweide \\ Marktredwitz, Klinikum Fichtelgebirge \\ Memmingen, Klinikum \\ München, Urologische Universitätsklinik Großhadern \\ Pfullingen, Praxisklinik Dr. Pesendorfer \\ Schwedt, Klinikum Uckermark \\ Weiden, Klinikum \\ Wesel, Marien-Hospital \\ Zirndorf, Praxisklinik Dr. Bismarck
}

\section{References}

$\checkmark 1$ Znaor A, Lortet-Tieulent J, Jemal A, Bray F: International variations and trends in testicular cancer incidence and mortality. Eur Urol 2014;65:1095-1106.

-2 Albers P, Albrecht W, Algaba F, Bokemeyer C, Cohn-Cedermark G, Fizazi K, Horwich A, Laguna MP: EAU guidelines on testicular cancer: 2011 update. Eur Urol 2011;60:304319.

-3 Ruf CG, Isbarn H, Wagner W, Fisch M, Matthies C, Dieckmann KP: Changes in epidemiologic features of testicular germ cell cancer: age at diagnosis and relative frequency of seminoma are constantly and significantly increasing. Urol Oncol 2014;32:33.e1-e6.

-4 Sokoloff MH, Joyce GF, Wise M; Urologic Diseases in America Project: Testis cancer. J Urol 2007;177:2030-2041.

5 Heinzelbecker J, Katzmarzik M, Weiss C, Trojan L, Michel MS, Haecker A: Changes of stage, predictive factors and adjuvant treatment modalities in seminomatous testicular cancer from 1987 to 2007 and their impact on the status of metastasis, recurrence-free and overall survival: a single-center analysis. Urol Int 2011;87:282-287.

-6 Fosså SD, Aass N, Kaalhus O: Radiotherapy for testicular seminoma stage I: treatment results and long-term post-irradiation morbidity in 365 patients. Int J Radiat Oncol Biol Phys 1989;16:383-388.

7 Horwich A: Radiotherapy in stage I seminoma of the testis. J Clin Oncol 2004;22:585588.

8 Classen J, Schmidberger H, Meisner C, Winkler C, Dunst J, Souchon R, Weissbach L, Budach V, Alberti W, Bamberg M; German Testicular Cancer Study Group (GTCSG): Paraaortic irradiation for stage I testicular seminoma: results of a prospective study in 675 patients. A trial of the German testicular cancer study group (GTCSG). Br J Cancer 2004;90:2305-2311.

-9 Siekiera J, Małkowski B, Jóźwicki W, Jasiński M, Wronczewski A, Pietrzak T, Chmielowska E, Petrus A, Kamecki K, Mikołajczak W, Kraśnicki K, Chłosta P, Drewa T: Can we rely on PET in the follow-up of advanced seminoma patients? Urol Int 2012;88:405409.

10 Horwich A, Fossa SD, Huddart R, Dearnaley DP, Stenning S, Aresu M, Bliss JM, Hall E: Second cancer risk and mortality in men treated with radiotherapy for stage I seminoma. Br J Cancer 2014;110:256-263.

11 Oliver RT, Hope-Stone HF, Blandy JP: Justification of the use of surveillance in the management of stage I germ cell tumours of the testis. Br J Urol 1983;55:760-763.

12 Peckham MJ, Hamilton CR, Horwich A, Hendry WF: Surveillance after orchiectomy for stage I seminoma of the testis. Br J Urol 1987; 59:343-347.

13 Peckham MJ, Horwich A, Hendry WF: Advanced seminoma: treatment with cis-platinum-based combination chemotherapy or carboplatin (JM8). Br J Cancer 1985;52:713.

14 Oliver RT, Lore S, Ong J: Alternatives to radiotherapy in the management of seminoma. Br J Urol 1990;65:61-67.

15 Oliver RT, Mason MD, Mead GM, von der Maase H, Rustin GJ, Joffe JK, de Wit R, Aass N, Graham JD, Coleman R, Kirk SJ, Stenning SP; MRC TE19 Collaborators and the EORTC 30982 Collaborators: Radiotherapy versus single-dose carboplatin in adjuvant treatment of stage I seminoma: a randomised trial. Lancet 2005;366:293-300.

-16 Classen J, Souchon R, Hehr T, Bamberg M: Treatment of early stage testicular seminoma. J Cancer Res Clin Oncol 2001;127:475481.

17 Motzer RJ, Agarwal N, Beard C, Bhayani S, Bolger GB, Buyyounouski MK, Carducci MA, Chang SS, Choueiri TK, Gupta S, Hancock SL, Hudes GR, Jonasch E, Kuzel TM, Lau C, Levine EG, Lin DW, Margolin KA, Michaelson MD, Olencki T, Pili R, Ratliff TW, Redman BG, Robertson CN, Ryan CJ, Sheinfeld J, Wang J, Wilder RB; National Comprehensive Cancer Network: Testicular cancer. J Natl Compr Canc Netw 2012;10: 502-535.
8 Beyer J, Albers P, Altena R, Aparicio J, Bokemeyer C, Busch J, Cathomas R, Cavallin-Stahl E, Clarke NW, Claßen J, Cohn-Cedermark G, Dahl AA, Daugaard G, De Giorgi U, De Santis M, De Wit M, De Wit R, Dieckmann KP, Fenner M, Fizazi K, Flechon A, Fossa SD, Germá Lluch JR, Gietema JA, Gillessen S, Giwercman A, Hartmann JT, Heidenreich A, Hentrich M, Honecker F, Horwich A, Huddart RA, Kliesch S, Kollmannsberger C, Krege S, Laguna MP, Looijenga LH, Lorch A, Lotz JP, Mayer F, Necchi A, Nicolai N, Nuver J, Oechsle K, Oldenburg J, Oosterhuis JW, Powles T, Rajpert-De Meyts E, Rick O, Rosti G, Salvioni R, Schrader M, Schweyer S, Sedlmayer F, Sohaib A, Souchon R, Tandstad T, Winter C, Wittekind C: Maintaining success, reducing treatment burden, focusing on survivorship: highlights from the third European consensus conference on diagnosis and treatment of germ-cell cancer. Ann Oncol 2013; 24:878-888.

19 Schmoll HJ, Jordan K, Huddart R, Pes MP, Horwich A, Fizazi K, Kataja V: Testicular seminoma: ESMO clinical practice guidelines for diagnosis, treatment and follow-up. Ann Oncol 2010;21(suppl 5):v140-v146.

20 Mottet N, Culine S, Iborra F, Avances C, Bastide C, Lesourd A, Michel F, Rigaud J: [Testicular tumors]. Prog Urol 2007; 17:10351045.

21 Howard GC, Nairn M; Guideline Development Group: Management of adult testicular germ cell tumours: summary of updated SIGN guideline. BMJ 2011;342:d2005.

22 De Giorgi U, Nicolai N, Tana S, Tavolini IM, Palazzi S, Bracarda S, Tedeschi L, Palmieri G, Frassineti L, Da Pozzo L, Pastorino U, Emiliani E, Marangolo M, Pizzocaro G, Rosti G, Salvioni R: IGG practice guidelines on germ cell tumor in adult male patients. Tumori 2008;94:96-109.

23 Dieckmann KP: Seminom klinisches Stadium I: immer noch Fragen offen. Die NSRStudie - eine bundesweite Studie zur Versorgungsforschung. Urologe A 2009;48:419422 . 
-24 Krege S, Beyer J, Souchon R, Albers P, Albrecht W, Algaba F, Bamberg M, Bodrogi I, Bokemeyer C, Cavallin-Ståhl E, Classen J, Clemm C, Cohn-Cedermark G, Culine S, Daugaard G, De Mulder PH, De Santis M, de Wit M, de Wit R, Derigs HG, Dieckmann KP, Dieing A, Droz JP, Fenner M, Fizazi K, Flechon A, Fosså SD, del Muro XG, Gauler T, Geczi L, Gerl A, Germa-Lluch JR, Gillessen S, Hartmann JT, Hartmann M, Heidenreich A, Hoeltl W, Horwich A, Huddart R, Jewett M, Joffe J, Jones WG, Kisbenedek L, Klepp O, Kliesch S, Koehrmann KU, Kollmannsberger C, Kuczyk M, Laguna P, Galvis OL, Loy V, Mason MD, Mead GM, Mueller R, Nichols C, Nicolai N, Oliver T, Ondrus D, Oosterhof GO, Paz-Ares L, Pizzocaro G, Pont J, Pottek T, Powles T, Rick O, Rosti G, Salvioni R, Scheiderbauer J, Schmelz HU, Schmidberger H, Schmoll HJ, Schrader M, Sedlmayer F, Skakkebaek NE, Sohaib A, Tjulandin S, Warde P, Weinknecht S, Weissbach L, Wittekind C, Winter E, Wood L, von der Maase $\mathrm{H}$ : European consensus conference on diagnosis and treatment of germ cell cancer: a report of the second meeting of the European germ cell cancer consensus group (EGCCCG): part I. Eur Urol 2008;53:478-496.

-25 Schrader M, Weissbach L, Hartmann M, Krege S, Albers P, Miller K, Heidenreich A: Burden or relief: do second-opinion centers influence the quality of care delivered to patients with testicular germ cell cancer? Eur Urol 2010;57:867-872.

-26 Zengerling F, Hartmann M, Heidenreich A, Krege S, Albers P, Karl A, Weissbach L, Wagner W, Bedke J, Retz M, Schmelz HU, Kliesch S, Kuczyk M, Winter E, Pottek T, Dieckmann KP, Schrader AJ, Schrader M: German second-opinion network for testicular cancer: sealing the leaky pipe between evidence and clinical practice. Oncol Rep 2014;31:24772481.
Zengerling F, Müller J, Schrader AJ, Schrader $\mathrm{M}$ : [Clinical stage I seminoma. Is surveillance a new therapy standard?]. Urologe A 2013;52: $1265-1269$

28 Vossen CY, Horwich A, Daugaard G, van Poppel H, Osanto S: Patterns of care in the management of seminoma stage I: results from a European survey. BJU Int 2012;110: 524-531.

29 Tandstad T, Smaaland R, Solberg A, Bremnes RM, Langberg CW, Laurell A, Stierner UK, Ståhl O, Cavallin-Ståhl EK, Klepp OH, Dahl O, Cohn-Cedermark G: Management of seminomatous testicular cancer: a binational prospective population-based study from the Swedish Norwegian testicular cancer study group. J Clin Oncol 2011;29:719-725.

30 Cafferty FH, Gabe R, Huddart RA, Rustin G, Williams MP, Stenning SP, Bara A, Bathia R, Freeman SC, Alder L, Joffe JK: UK management practices in stage I seminoma and the medical research council trial of imaging and schedule in seminoma testis managed with surveillance. Clin Oncol (R Coll Radiol) 2012; 24:25-29.

31 Grimison P, Houghton B, Chatfield M, Toner GC, Davis ID, Martin J, Hovey E, Stockler MR: Patterns of management and surveillance imaging amongst medical oncologists in Australia for stage I testicular cancer. BJU Int 2013;112:E35-E43.

32 Bilici A, Ozturk T, Turkmen E, Odabas H, Cihan S, Selcukbiricik F, Erdogan B, Urakci Z, Kandemir N, Bayoglu IV, Demirci U, Duran AO, Sendur MA, Yavuzer D, Harputluoglu H, Kavgaci H, Gumus M: Treatment preferences in stage IA and IB testicular seminoma: multicenter study of Anatolian society of medical oncology. World J Urol 2015;33:1613-1622.
33 Kohut RM Jr, Minnillo BJ, Kypriotakis G, Abouassaly R, Zhu H: Changes in adjuvant therapy utilization in stage I seminoma: are they enough to prevent overtreatment? Urology 2014;84:1319-1324.

34 Scriba PC, Berger J: Versorgungsforschung: die Förderinitiative der Bundesärztekammer. Dtsch Med Wochenschr 2007;132:1424-1426.

35 Hoffmann F, Glaeske G: [Health services research in oncology using claims data]. Med Klin (Munich) 2010;105:409-415.

36 Ernstmann N: [On the importance of health services research: an overview]. Urologe A 2011;50:673-677.

37 Vlayen J, Vrijens F, Devriese S, Beirens K, Van Eycken E, Stordeur S: Quality indicators for testicular cancer: a population-based study. Eur J Cancer 2011;48:1133-1140.

- 38 Bagnell S, Choo R, Klotz LH, Chaterjee S: Practice patterns of Canadian urologists in the management of stage I testicular seminoma. Can J Urol 2004;11:2194-2199.

-39 Warde P, Specht L, Horwich A, Oliver T, Panzarella T, Gospodarowicz M, von Der Maase $\mathrm{H}$ : Prognostic factors for relapse in stage I seminoma managed by surveillance: a pooled analysis. J Clin Oncol 2002;20:4448-4452.

40 Dieckmann KP, Brüggeboes B, Pichlmeier U, Küster J, Müllerleile U, Bartels H: Adjuvant treatment of clinical stage I seminoma: is a single course of carboplatin sufficient? Urology 2000;55:102-106.

41 Gray PJ, Lin CC, Sineshaw H, Paly JJ, Jemal A, Efstathiou JA: Management trends in stage I testicular seminoma: impact of race, insurance status, and treatment facility. Cancer 2015;121:681-687.

42 Hoffman KE, Chen MH, Punglia RS, Beard CJ, D'Amico AV: Influence of year of diagnosis, patient age, and sociodemographic status on recommending adjuvant radiation treatment for stage I testicular seminoma. J Clin Oncol 2008;26:3937-3942. 